論 文

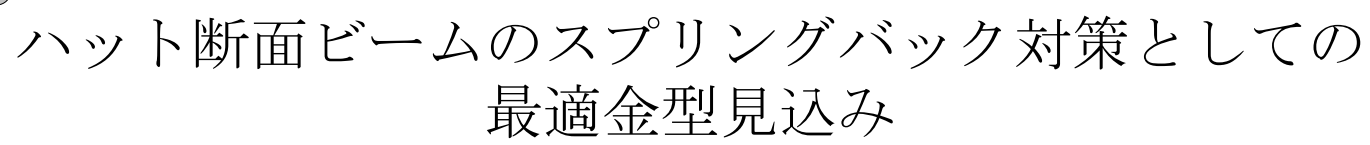

安部 重毅* 日野 隆太郎** 近藤 裕樹*** 吉田 総仁**

\title{
Optimum Springback Compensation for Hat-Shaped Beam Forming
}

\author{
Shigeki ABE*, Ryutaro HINO ${ }^{* *}$, Hiroki KONDO ${ }^{* * *}$ and Fusahito YOSHIDA **
}

(Received on January 23, 2008)

\begin{abstract}
A new method of springback compensation for a hat-shaped beam based on finite element (FE) simulation and the optimization technique is presented, in which the objective function to be minimized is the shape error of the press-formed beam after springback and the design variables are the geometrical parameters for defining the die shape. This method starts with rough die compensation based on empirical knowledge and springforward analysis, and then optimization is carried out. To reduce the computation time in optimization, the idea of two-step optimization is presented, where the die cross-sectional shape and longitudinal die curvature are determined separately. In addition, a partial FE model, which is less expensive computationally, is used in die cross-sectional shape optimization, instead of a full FE model. In this paper, we describe the general method of die compensation, the formulation of the optimization problem, details of the numerical technique, and the verification of this method by solving a springback problem for the beam model.
\end{abstract}

Key words : sheet metal forming, elastic-plastic FEM, springback, process design, optimization.

\section{1. 緒 言}

自動車の軽量化に伴い，高張力鋼板の構造部材への適用 範囲が拡大している。この高張力鋼板は従来の軟鋼板に比 ベ，プレス成形時に割れ，しわ，スプリングバックといっ た不具合が顕著に発生する．特にスプリングバックに起因 する開き，反り，ねじれなどの形状不良の対策が生産現場 で多大な負担となっている.

筆者らは，ハット断面形状を持つ長尺部品特有のねじれ を解消するために，ドロービードの高さを設計変数として 扱い，最適化手法により成形シミュレーション上で最適な ドロービード形状を決定する方法を提案した ${ }^{1)}$. 提案方法 の評価には S レイルモデルを，供試材には $1 \mathrm{GPa}$ 級の超高 張力鋼板を採用した. 提案方法の有効性を確認するために, 成形シミュレーション上で決定した最適なドロービードを S レイルの実金型に配置し，実証実験を行ったところ，予 想通りねじれを解消できた。 このようなアプローチが成功 したのは，最適化計算において高精度なスプリングバック 解析を可能にする Yoshida-Uemori モデル2 2) 3)を使用したこ とによる効果が大きい.

\footnotetext{
“広島県立総合技術研究所 西部工業技術センター 生産技術アカデミー 干739-0046 東広島市鏡山 3-13-26

Academy for Manufacturing Technology, West Region Industrial Research Center, Hiroshima Prefectural Technology Research Institute

3-13-26 Kagamiyama, Higashi-Hiroshima, 739-0046, Japan.

* 広島大学大学院工学研究科 ₹ 739-8527 東広島市鏡山 1-4-1

Department of Mechanical Sysem Engineering, Hiroshima University

1-4-1 Kagamiyama, Higashi-Hiroshima, 739-8527, Japan.

** (株)イテック テ 736-0003 広島県安芸郡海田町曽田 3-74

Y-tec Corporation, 3-74 Soda, Kaita-cho, Aki-gun, Hiroshima, 736-0003, Japan.
}

この最適化手法は成形条件を変更しつつ成形シミュレー ションを何度も繰り返し, 効率よく不具合の無い成形条件 を決定するものである。ここで問題となるのは，高精度な 成形シミュレーションをベースに最適化を行うと， 1 回あ たりの解析時間が長くなり，最適化の総計算時間が膨大に なり, 現実的な時間範囲内での解析が不可能になる.

日野らは角筒深絞りのブランク形状最適化において, 要 素サイズが粗く解析時間の短い “簡易モデル” と従来の要 素サイズの “詳細モデル”を併用して短時間で最適解を得 る方法を提案した。これにより総計算時間を $85 \%$ 短縮して いる ${ }^{4)}$.ただし,要素サイズが粗いモデルはスプリングバッ クの解析精度を極端に低下させるため, S レイルのような 最適化事例には適用できない.

本報では，対象とする問題の特性に応じて，相関の低い 設計変数の分離, 適切な部分モデルの導入, 経験に基づく 見込みなどの導入を行うことで，板成形問題最適化（特に スプリングバック解析を含む計算負荷の高い最適化）を高 精度かつ短時間で行う方法を提案し, 具体的な成形問題一 の適用によって，その有効性を示す。対象モデルはハット 断面を円弧状に繋げたビーム部品とする. 改善したい不具 合はスプリングバックによる形状不良とする。ここでは, スプリングバックの見込み分だけ，対象モデルの金型を修 正して, 形状不良を改善する。この金型はハット状の横断 面とこれに直交する円弧状の長手方向断面で定義できる. そこで，各断面の形状寸法を設計変数とし，これを変更し つつ金型形状を最適化する.

この金型形状の最適化に要する総計算時間を次の 2 つの 
手法によって短縮する. 最初の手法は最適化の前準備段階 で形状不良をできるだけ改善しておくことである。これに より最適化実施時の解析回数を削減できる．2 番目の手法 は, 相関の低い設計変数を 2 つに分離し, それぞれ別の最 適化計算で決定し, 総解析回数を削減することである. こ こでは “金型の横断面形状の最適化” と“金型の長手方向 の断面形状の最適化”の 2 つの最適化を行う. 横断面形状の 最適化では, 解析範囲をモデルの一部に限定する “部分モ デル”を採用し，さらなる総計算時間の短縮を図る。これ らの手法を用いることにより，極めて短い時間で全体の $80 \%$ 以上のエリアで目標形状との差異が $0.5 \mathrm{~mm}$ 以内の成 形を可能にする金型形状を決定できた.

\section{2. ハット断面ビームに生じる形状不良}

ハット断面ビームはハット断面が上向き円弧に沿って繋 がっている円弧長さ $900 \mathrm{~mm}$ の長尺プレス部品であり, フ オーム成形で加工する. Fig.1 にその形状寸法を示し, 以後 この形状を目標形状と呼ぶ. この部品のハット状の横断面 に垂直な方向を $\mathrm{X}$ 方向, 円弧状の長手方向断面に垂直な方 向を $\mathrm{Y}$ 方向，プレス成形の反対方向を Z 方向とする.

ハット断面ビームの加工で使用するブランクは Table 1 のような機械的性質を持つ板厚 $1.2 \mathrm{~mm}$ の $1 \mathrm{GPa}$ 級の超高張 力鋼板とし, 成形前形状は $900 \mathrm{~mm} \times 168 \mathrm{~mm}$ とする。この ブランクを横断面中央側で $220 \mathrm{kN}$ のカでパッドとパンチに 挟みつつ，パンチをZ 方向に下ろして加工する.

この加工を成形シミュレーションにより解析する. ハッ 卜断面ビームは原点を通る横断面, 長手方向断面で対称で あるため, 解析対象エリアを $1 / 4$ に限定する (Fig.2(a)参照). この $1 / 4$ のエリアを成形する金型モデルを $1 / 4$ 全体モデル と呼ぶ。このモデルの 1 回あたりの解析時間は, 約 1.5 時 間である.成形シミュレーションはPAM-STAMP(ESI 社), その材料モデルには Yoshida-Uemori モデルを使用した。

目標形状どおりの金型モデル Model-0 を作成し，成形シ ミュレーションにてフォーム成形，スプリングバックの順 で解析を行った. Fig.2(b)左図に Model-0 の 1/4 全体モデル を, 右図にスプリングバック解析後の解析結果を示す.

Fig.3 は横断面と長手方向断面で目標形状と解析結果を比 較した図である。スプリングバックにより横断面では，た て壁が外側に 11.8 度開き, 長手方向断面では端部が $9.4 \mathrm{~mm}$

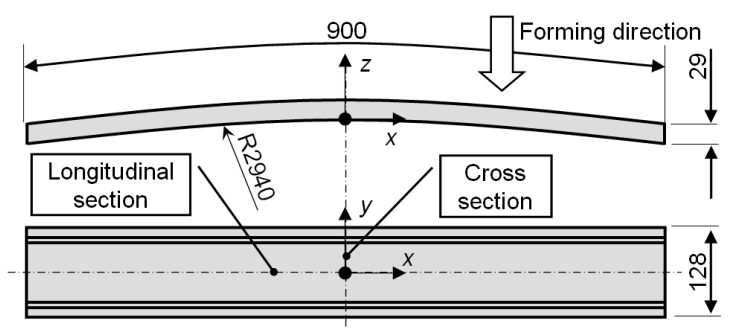

Fig.1 Hat-shaped beam model (target shape)

Table 1 Mechanical properties of blank sheet

\begin{tabular}{|c|c|c|c|c|}
\hline $\begin{array}{c}\text { Yield } \\
\text { strength } \\
/ \mathrm{MPa}\end{array}$ & $\begin{array}{c}\text { Tensile } \\
\text { strength } \\
/ \mathrm{MPa}\end{array}$ & $\begin{array}{c}\text { Elongation } \\
/ \%\end{array}$ & $n$-value & $r$-value \\
\hline 683 & 1094 & 15.8 & 0.124 & 0.80 \\
\hline
\end{tabular}

戻り, 形状不良となる. 本研究の目的は, この形状不良を 改善することである. 改善手段として金型形状にスプリン グバックの弾性回復分の見込み修正を加える。つまり，ス プリングバック後に目標形状と一致するように弾性回復の 変形量分だけフォーム成形中に余分に変形させる. Model-0 へ見込み分の形状修正を加えた金型形状を最適化手法で決 定する.

\section{3. 大まかな金型見込み形状の決定}

見込みを全く入れない金型形状 Model-0 を用いて成形シ ミュレーションを行うと, Fig.3のように目標形状と解析結 果との間に大きな形状差がでる.この形状差が大きいほど, 金型形状の大規模な修正が不可欠となり，それに伴い最適 化計算における解析結果を目標形状に合わせこむための解 析回数が増加する.

そこで, 最適化の前準備段階で “スプリングフォワード 解析” ‘ “形状不良の改善方案” といった後述する方法に て，大まかな金型見込み形状を決定する，これを用いて目 標形状に解析結果を近づけることができるため, 最適化計 算実施時の解析回数を削減できる.



(a) 3D-shape of hat-shaped beam

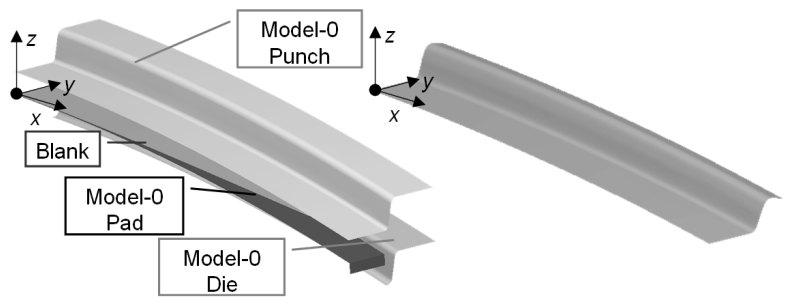

(b) 1/4 full model of tools and formed part shape after springback

Fig.2 1/4 full model for FE simulation

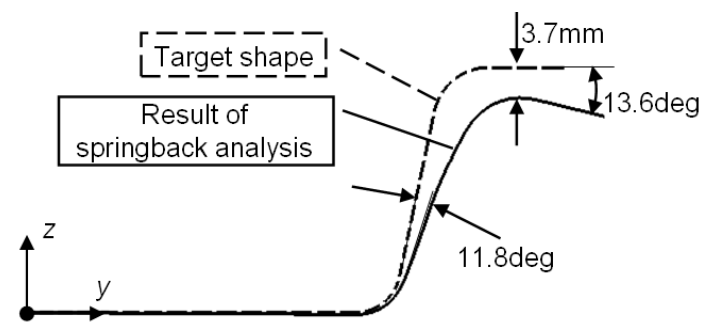

(a) Shape error at cross section

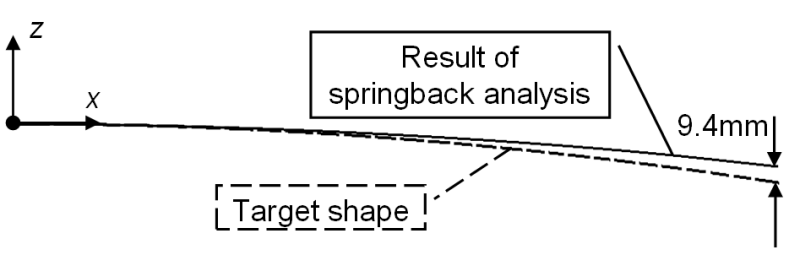

(b) Shape error at longitudinal section

Fig.3 Target shape and FE simulation result using Model-0 (no die compensation) 
3.1 スプリングフォワード解析による主要寸法の決定

金型見込み形状を 1 回の解析で算出する手法としてスプ リングフォワード計算がある。これは目標形状どおりの金 型を用いてフォーム成形解析を行い，その後ブランクが持 つ内部応力の符号を反転させ，その状態からスプリングバ ック解析を行うものである. これは PAM-STAMP 2G の保 有機能である. Fig.4 は横断面と長手方向断面におけるスプ リングフォワードの解析結果形状であり，この結果形状に 沿う金型形状が見込みを入れた金型形状となる。この金型 形状を用いてフォーム成形解析を行い，かつ目標形状どお りの金型形状で成形した場合と類似した内部応力をブラン クに分布できたとする，その場合，スプリングバック後の 解析結果が目標形状にほぼ一致する.

しかし，スプリングフォワード解析による金型見込みに も問題がある. Fig.4(a)下図のようにたて壁が内側に入り込 むアンダーカットが生じる場合には，金型形状として成立 しない.ここでは，スプリングフォワード解析より得られ るダイフェイスの傾斜角 $\mathrm{A} 1$ ，たて壁の傾き角 $\mathrm{A} 2$ ，長手方 向の曲率半径 R1 を大まかな金型見込みの主要寸法として 採用する.

\section{2 形状不良の改善方案}

見込みの導入だけでは超高張力鋼板の壁反り対策は不十 分である.ここでは金型に，たて壁に反り方向と逆向きの 曲率による見込みを入れる，たて壁の開きを改善するため



(a) Cross section

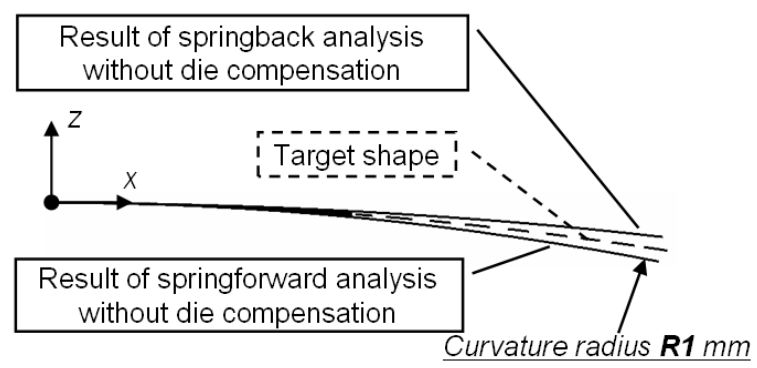

(b) Longitudinal curvature

Fig.4 Die compensation based on springforward analysis
にパンチ底 $\mathrm{R}$ の寸法を小さくする, 成形途中のブランクの 曲げ角を小さくするという 3 点の改良を金型形状に加えた

(Fig.5 参照).

以上のように決定した金型モデルを Model-1 とし，これ を Fig.5 右図に示す. 金型 Model-1 で成形した解析結果と 目標形状を並べた図を Fig.6 に示す。これより，見込みを 全く入れない金型 Model-0 を用いた解析結果に比べ, 目標 形状との差異が大幅に減少しており，大まかな見込みが十 分な効果を挙げていると言える。しかし，Model-1 の金型 形状だけでは目標形状に重なっておらず，まだ十分とはい えない. そこで，さらに金型見込み形状の最適化を行う.

\section{4. 最適な金型形状の決定}

成形シミュレーションを用いた最適化には, 総計算時間 が長いという問題がある。最適化の総計算時間は 1 回あた りの解析時間に最適化計算における解析回数をかけ合わせ た時間となる.解析時間はブランクの要素サイズが細かく, かつ構成要素数が多いほど長い. また, 最適解に至るまで の解析回数は設計変数の数が多いほど増える.

本報では金型見込み形状の最適化に要する総計算時間を 短縮するために, 相関の低い設計変数を分離して別々に最 適化する.さらに可能であれば最適化で使用する成形シミ ユレーションのモデルを部分モデルで代替し，1回あたり の解析時間を短縮する。

最適化の対象となる金型形状は横断面と長手方向断面に 分けることができるため, 各断面ごとの形状寸法をお互い に相関の低い設計変数とし, 別々に最適化を行う. 最初に 部分モデルを用いてハット形状の金型横断面を最適化する. 次に最適な金型横断面を反映させた $1 / 4$ 全体モデルを用い て円弧状の金型の長手方向断面を最適化する，得られる最 適金型形状は，最適な金型横断面を長手方向の最適金型断 面の形状に沿わせて押し出した形状とする。



Fig.5 Further die compensation based on empirical knowledge



Fig.6 Target shape and FE simulation result using Model-0 and Model-1 (rough die compensation based on empirical knowledge and springforward analysis) at cross section 


\section{1 金型の横断面形状の最適化}

ハット断面ビームの金型横断面はハット形状であるため, 長手方向断面に比べて複雑である. そのため解析結果を目 標形状に精度よく合わせこむには，形状を決定する設計変 数を多く用意する必要があるが，それに伴い解析回数が大 幅に増加することが懸念される。ここでは,最適化の総計算 時間を短縮するため, 設計変数を 3 個にしぼり，さらに 1 回の解析時間が 4 分弱の部分モデルの採用を検討した.

Fig.7(a)に示すように部分モデルは中央の横断面付近の 金型モデルを切り取り，これに幅 $10 \mathrm{~mm}$ のブランクを配置 したものである． 前節の金型 Model-1 を切り出した部分モ デルと $1 / 4$ 全体モデルをそれぞれ用いて成形シミュレーシ ヨンを行った.各々の解析結果を並べた図を Fig.7(b)に示す. 中央横断面における解析結果の形状誤差は最大 $0.55 \mathrm{~mm}$ と 少なく, 補正を加えれば部分モデルを最適化計算に使用で きると判断した.

本節では目標断面形状に解析結果が一致する最適な金型 横断面形状を，部分モデルを用いて決定する．本最適化問 題は次のように要約できる.

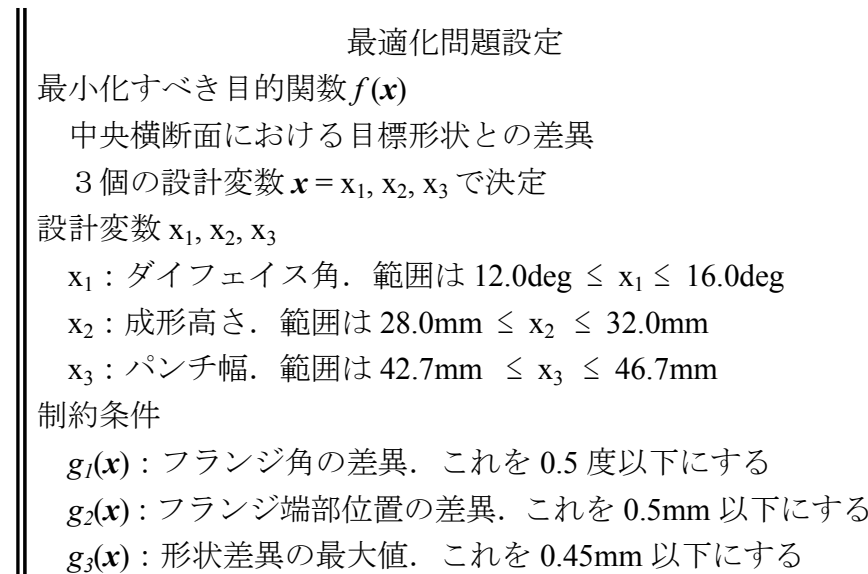

金型横断面形状を決定する設計変数は Fig.8 のように金 型のダイフェイス角 $\mathrm{x}_{1}$, 成形高さ $\mathrm{x}_{2}$, パンチ幅 $\mathrm{x}_{3}$ の 3 項目 とし，モーフィングにより形状変更をさせる. 目的関数は 複数の箇所で解析結果と目標形状との差異を計算し, その 差異の総和とする. 最適化ではこの目的関数の值を最小化 する. 制約条件は目標形状に対する相対的なフランジ角, フランジ端部位置, 差異の最大值の 3 項目とし,それぞれを 規定值以下に抑えることとする. また目的関数や制約関数 を計算する時には，比較基準となる目標断面形状に $1 / 4$ 全 体モデルと部分モデルの形状誤差分の補正を一律に加える。

最適化計算では, 初期金型形状として 3 章で決定した金 型 Model-1 を使用し, 最適化エンジンには逐次応答曲面法 を用いた Hyper Opt（Altair Engineering 社）を使用した。

最適化計算は 37 回（最適解は 20 回目）で完了した. Fig.9(a)に最適金型横断面とそれを用いた解析結果を示す. 解析結果が目標形状によく一致していることがわかる. 目 的関数, 制約関数の結果を Table 2 に示す.

\section{2 金型の長手方向の断面形状の最適化}

次に金型横断面と直交する長手方向の金型断面形状を決 定する. 金型横断面の最適化ではX 方向の製品断面が全て 同じであるため，部分モデルを使用したが，Y 方向の製品
断面にはこれが当てはまらない. 本節では最適な金型横断 面を反映させた $1 / 4$ 全体モデルの長手方向断面をモーフィ ングにより形状変更しつつ, 最適な金型長手方向断面形状 を決定する．本最適化問題は次のように要約できる.

\section{最適化問題設定}

最小化すべき目的関数 $f(\mathrm{x})$

長手方向の中央断面における目標形状との差異

1 個の設計変数 $\mathrm{x}$ で決定

設計変数 $\mathrm{x}$ :

$\mathrm{x}$ : 曲率半径. 範囲は $2200 \mathrm{~mm} \leq \mathrm{x} \leq 2500 \mathrm{~mm}$ 制約条件：

$g(\mathrm{x})$ : 形状差異の最大值. これを $0.5 \mathrm{~mm}$ 以下にする

長手方向の金型断面の最適化では，目標形状の曲率が一 定であるため, 設計変数は金型形状の曲率半径だけとする. 目的関数は長手方向断面における解析結果と目標形状との

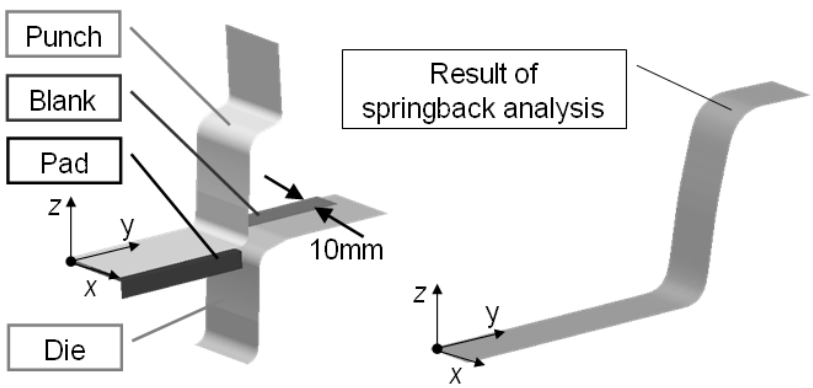

(a) Partial model and FE simulation result after springback

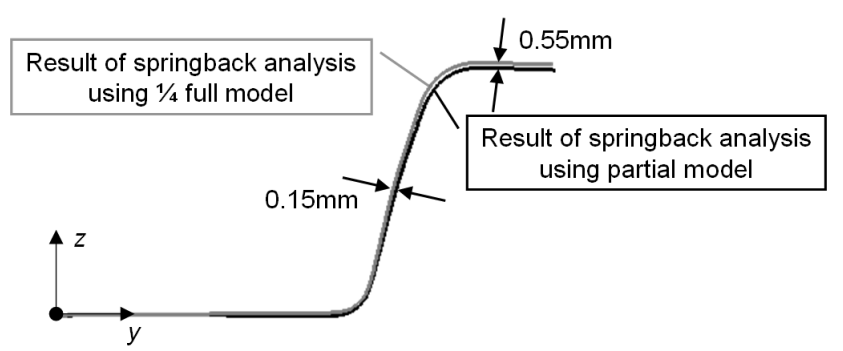

(b) Comparison of FE simulation between partial model and 1/4 full model for springback analysis

Fig.7 Partial model of hat-shaped beam forming

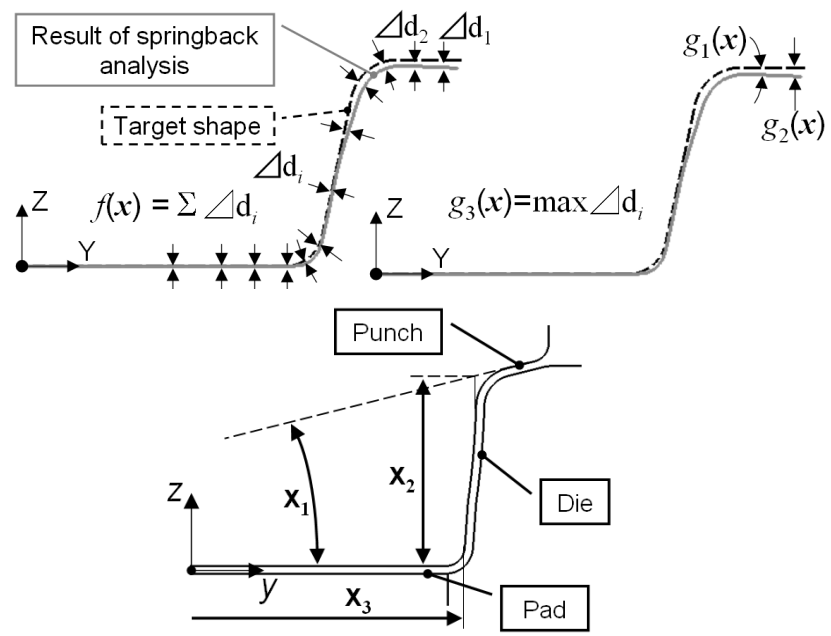

Fig.8 Definitions of objective function $f(\boldsymbol{x})$, constraints $g(\boldsymbol{x})$ and design valuables $\boldsymbol{x}=\mathrm{x}_{1}, \mathrm{x}_{2}, \mathrm{x}_{3}$ for optimization 
差異を複数の点で抽出し, その総和とする. 最適化ではこ の目的関数の值を最小化する. 制約条件は長手方向断面に おける差異の最大值を規定值以下に抑えることとする.

最適化計算は設計変数が 1 個であるため, わずか 8 回で 完了した. Fig.9(b)に示すように最適金型長手方向断面を使 用した解析結果は目標形状とよく一致している.目的関数, 制約関数の結果を Table 3 に示す.

\section{3 最適化結果と最適化の総計算時間}

見込みを入れない場合の金型（Model-0)，3 章の大まか な見込みを入れた金型（Model-1），4章の最適化をした金 型（Model-2）をそれぞれ使用した解析結果と目標形状との 形状差を比較した。目標形状との差異の最大值は Model-0 が $9.41 \mathrm{~mm}$, Model-1 が $1.88 \mathrm{~mm}$ に対し Model-2 が $1.29 \mathrm{~mm}$ と順に改善していることがわかる.

解析結果と目標形状との差異のコンター図を Fig.10(a)に, 差異の程度と全面積に占める割合の関係を表すグラフを Fig.10(b)に示す．色が濃いエリアが多いほど目標形状との 差異が大きく, 薄いほど差異が少ないことを示す. Model-0 では $0.5 \mathrm{~mm}$ 以内の差異の面積が全体の $21 \%$ であったのに 対し, Model-1 では 65\%, Model-2 では 80\%以上となり, 最適化の効果が伺える.

金型形状の最適化の総計算時間は，全部で 868 分であっ た. その内訳は横断面の最適化が 148 分（4 分/回 $\times 37$ 回） で全体の $17.1 \%$ ，長手方向断面の最適化が 720 分（90 分/ 回 $\times 8$ 回）で全体の $82.9 \%$ であった. 仮に最適化の計算を 2 回に分けない場合を想定すると, 解析回数は少なくとも 45 回（37 回+8 回）で部分モデルが使えないため, 4,050 分（45 回 $\times 90$ 分）以上の計算時間がかかる. この手法を 用いることで約 $1 / 5$ に総計算時間を短縮できたといえる.

\section{5. 結 言}

最適化計算前に大まかな見込みを入れる，最適化計算を 2 段階に分ける，さらに部分モデルを使用することにより ハット断面ビームのスプリングバックを見込んだ最適金型 形状を短時間で決定できた事例を報告した。

本報で示した方法論 (問題特性に応じた設計变数の分離, 部分モデルの利用, 従来の知見の反映)はビーム部品のフォ 一ム成形に限らず, 種々の成形条件最適化問題に対して有 効であると考えられる.

本研究は, 広島県産業科学技術研究所のプロジェクト「自 動車軽量化を目的とした難成形材の半凝固・塑性加工の開 発とその最適プロセス設計の研究」のもとで行われたこと を付記し, 参画メンバーの皆様に感謝の意を表します。

\section{参 考 文 献}

1）安部重毅・吉田総仁・日野隆太郎 : 塑性と加工, 48-562 (2007), 68-72.

2 ) Yoshida, F. \& Uemori, T.: Int. J. Plasticity, 18 (2002), 661-686.

3 ) Yoshida, F. \& Uemori, T.: Int. J. Mech. Sci., 45 (2003), 1687-1702.

$4)$ Hino, R. , Yoshida, F. \& Toropov, V. V.: Arch. Appl. Mech., 75 (2006), 679-691.

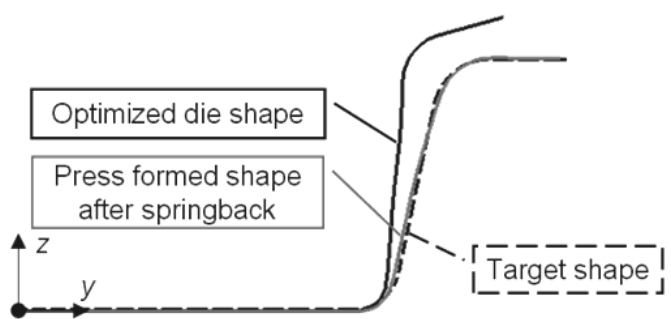

(a) Cross section

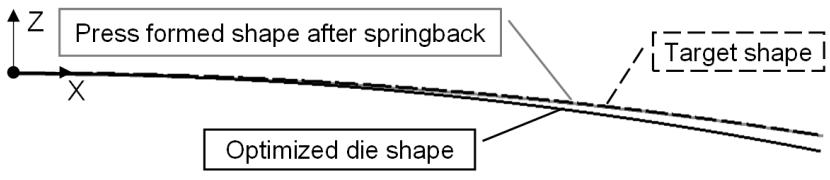

(b) Longitudinal curvature

Fig.9 Target shape and FE simulation result using Model-2 (accurate die compensation using optimization technique)

Table 2 Result of optimization for cross section of the beam

\begin{tabular}{|c|c|c|c|c|c|c|c|}
\hline & $f(\boldsymbol{x})$ & $g_{l}(\boldsymbol{x})$ & $g_{2}(\boldsymbol{x})$ & $g_{3}(\boldsymbol{x})$ & $\mathrm{x}_{1}$ & $\mathrm{x}_{2}$ & $\mathrm{x}_{3}$ \\
\hline $\begin{array}{c}\text { Initial } \\
\text { design }\end{array}$ & 17.7 & 1.69 & 1.034 & 1.086 & 13.9 & 29 & 43.5 \\
\hline $\begin{array}{c}\text { Optimum } \\
\text { design }\end{array}$ & 8.80 & 0.464 & 0.028 & 0.442 & 15.2 & 31.3 & 43.1 \\
\hline
\end{tabular}

Table 3 Result of optimization for longitudinal direction of the beam

\begin{tabular}{|c|c|c|c|}
\hline & $f(\mathrm{x})$ & $g(\mathrm{x})$ & $\mathrm{x}$ \\
\hline Initial design & 26.9 & 0.797 & 2320 \\
\hline Optimum design & 15.9 & 0.334 & 2352 \\
\hline
\end{tabular}

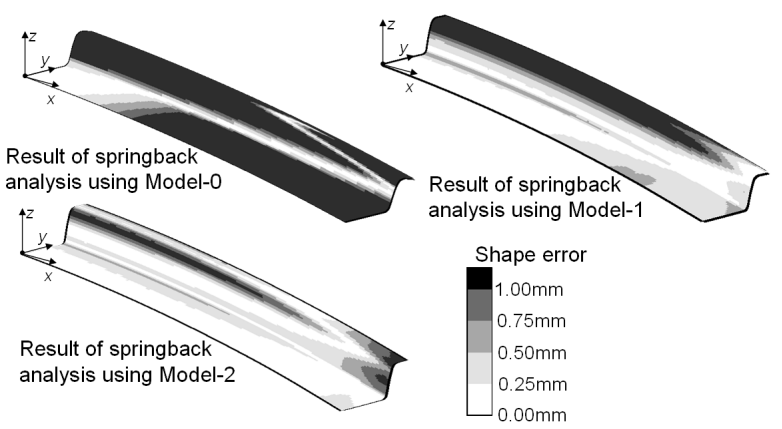

(a) Contours of shape errors between target shape and FE simulation result

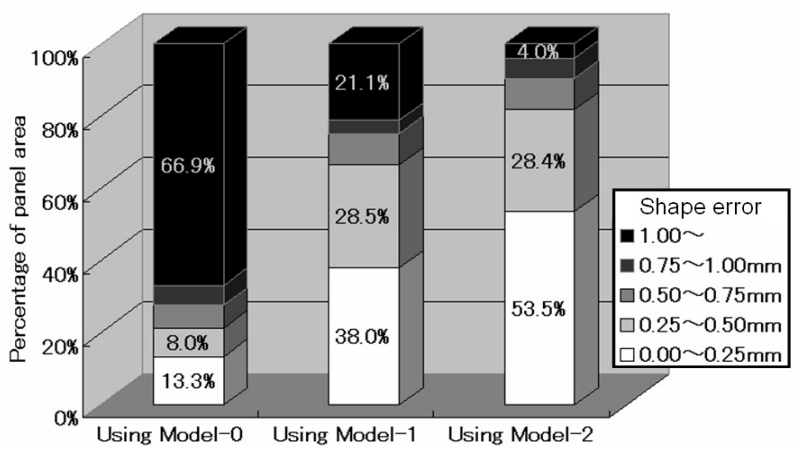

(b) Level of shape errors (percentage of panel area)

Fig.10 Shape errors at three stages of optimization ( Model-0, -1 and -2 ) 